\title{
Article \\ Efficacy and Safety of Dual-Drug-Eluting Stents for de Novo Coronary Lesions in South Korea-The Effect Trial
}

\author{
Jung-Joon Cha ${ }^{1}$, Gi Chang Kim ${ }^{2}$, Seung Ho Hur ${ }^{3}$, Jang Ho Bae ${ }^{4}$, Jae Woong Choi ${ }^{5} \mathbb{D}$, Dong-Kyu Jin ${ }^{6}$, \\ Seong Il Woo ${ }^{7}$, Seung Uk Lee ${ }^{8}{ }^{\mathbb{D}}$, Jong Seon Park ${ }^{9}$, Yun-Hyeong Cho ${ }^{10}$, Cheol Ung Choi ${ }^{11}$, Do-Sun Lim ${ }^{1}$ \\ and Tae Hoon Ahn 1,12,*
}

check for updates

Citation: Cha, J.-J.; Kim, G.C.; Hur, S.H.; Bae, J.H.; Choi, J.W.; Jin, D.-K.; Woo, S.I.; Lee, S.U.; Park, J.S.; Cho, Y.-H.; Choi, C.U.; Lim, D.-S.; Ahn, T.H. Efficacy and Safety of Dual-Drug-Eluting Stents for de Novo Coronary Lesions in South Korea-The Effect Trial. J. Clin. Med. 2021, 10, 69. https://dx.doi.org/ $10.3390 /$ jcm10010069

Received: 30 November 2020 Accepted: 22 December 2020 Published: 27 December 2020

Publisher's Note: MDPI stays neutral with regard to jurisdictional claims in published maps and institutional affiliations.

Copyright: (c) 2020 by the authors. Licensee MDPI, Basel, Switzerland. This article is an open access article distributed under the terms and conditions of the Creative Commons Attribution (CC BY) license (https: / / creativecommons.org/ licenses/by/4.0/).
1 Department of Cardiology, Cardiovascular Center, Korea University Anam Hospital, Korea University College of Medicine, Seoul 02841, Korea; joonletter@hanmail.net (J.-J.C.); dslmd@naver.com (D.-S.L.)

2 Department of Cardiology, Shihwa General Hospital, Siheung 15034, Korea; kimsan21@hanmail.net

3 Department of Cardiology, Keimyung University Hospital, Daegu 41931, Korea; shur@dsmc.or.kr

4 Department of Cardiology, Konyang University Hospital, Daejeon 35365, Korea; janghobae@yahoo.com

5 Department of Cardiology, Nowon Eulji Medical Center, Seoul 01830, Korea; cjw1108@eulji.ac.kr

6 Department of Internal Medicine, Soonchunhyang University Cheonan Hospital, Cheonan 31151, Korea; bluesky@schmc.ac.kr

7 Division of Cardiology, Department of Internal Medicine, Inha University School of Medicine, Incheon 22332, Korea; siwoo@inha.ac.kr

8 Department of Cardiology, Gwangju Christian Hospital, Gwangju 61661, Korea; cardiosu@hanmail.net

9 Department of Internal Medicine, College of Medicine, Yeungnam University, Daegu 42415, Korea; pjs@med.yu.ac.kr

10 Department of Internal Medicine, Hanyang University Myongji Hospital, Goyang 10475, Korea; princette@gmail.com

11 Department of Internal Medicine, Cardiovascular Center, Division of Cardiology, Korea University Guro Hospital, Korea University College of Medicine, Seoul 08308, Korea; wmagpie@korea.com

12 Department of Internal Medicine, Gachon University Gil Hospital, Incheon 21565, Korea

* Correspondence: ath3869@naver.com; Tel.: +82-2-920-5445

Abstract: Background: Drug-eluting stents (DESs) are commonly used in percutaneous coronary intervention (PCI) procedures; however, complications including in-stent restenosis and stent thrombosis are significant challenges. The dual-DES is a stent that elutes two drugs to target various stages of the restenosis reaction. This study investigated the safety and efficacy of dual-DES in clinical practice. Methods: This study included 375 patients who underwent PCI with Cilotax ${ }^{\mathrm{TM}}$ or $\mathrm{DXR}^{\mathrm{TM}}$ dual-DESs at one of 13 centers in South Korea. The primary endpoint was target lesion failure (TLF) within 1 year. The secondary endpoints were cardiac death, myocardial infarction (MI), target lesion revascularization (TLR), and stent thrombosis. Results: The rates of TLF in dual-DESs (3.7\%) were comparable to those reported in conventional DES. In addition, the DXR ${ }^{\mathrm{TM}}$ group had a significantly lower rate of TLF than the Cilotax ${ }^{\mathrm{TM}}$ group. In multivariate analysis, the $\mathrm{DXR}^{\mathrm{TM}}$ group had a lower risk of TLF (adjusted hazard ratio (HR) 0.30, 95\% CI 0.09-0.92, $p=0.036$ ) and MI (adjusted HR 0.16, 95\% CI 0.03-0.82, $p=0.027)$ than the Cilotax ${ }^{\text {TM }}$ group. Conclusion: Dual-DESs had similar clinical outcomes regarding efficacy and safety as conventional DES. Among the dual-DES, the DXR ${ }^{\mathrm{TM}}$ stent as a new generation dual-DES had more favorable clinical outcomes than the Cilotax ${ }^{\mathrm{TM}}$ stent.

Keywords: dual drug-eluting stent; Cilotax ${ }^{\mathrm{TM}}$ stent; $\mathrm{DXR}^{\mathrm{TM}}$ stent; coronary artery disease; clinical outcome

\section{Introduction}

Drug-eluting stents (DESs) are commonly used for percutaneous coronary intervention (PCI) due to their lower restenosis rates than bare-metal stents (BMS) [1,2]. However, late restenosis has been reported in some early DES designed to dissolve drugs using a metal body and polymer structure, and reactive and delayed endothelial cell proliferation due to the early generation polymer has been reported to result in early or late stent 
thrombosis [3-6]. Cilostazol, which has a similar antiplatelet effect to ticlopidine and a powerful inhibitory effect on phosphodiesterase [7-10], has been introduced as a new DES drug. Cilostazol has been reported to reduce the rate of restenosis after DES or BMS via its antiproliferative activity on vascular smooth muscle cells [11-14].

Dual-DESs are stents that elute two drugs to target various stages of the restenosis reaction. In South Korea, two new dual-DESs, composed of paclitaxel and cilostazol, are currently used: the first-generation dual-DES Cilotax ${ }^{\mathrm{TM}}$ and the second-generation dualDES DXR ${ }^{\mathrm{TM}}$. Paclitaxel and cilostazol prevent restenosis and stent thrombosis, respectively. This prospective, multicenter, observational study aimed to investigate the safety and effectiveness of these dual-DESs in patients who underwent PCI.

\section{Methods}

\subsection{Patients}

In this study, 389 patients who underwent PCI with a dual-DES (Cilotax ${ }^{\mathrm{TM}}$ or DXR ${ }^{\mathrm{TM}}$ (Cardiotec Co. Ltd., Seoul, Korea)) were enrolled from 13 hospitals in South Korea. Patients who had undergone PCI with different DES, those with a life expectancy $<1$ year, those with psychogenic shock or significantly reduced left ventricular function (left ventricular ejection fraction $<25 \%$ ), and those undergoing dialysis for chronic renal failure were excluded. Finally, 375 patients were included in the study. The follow-up period for clinical outcomes was 1 year. The patients were divided into groups based on the dual-DES used: the Cilotax ${ }^{\mathrm{TM}}$ group $(n=82)$ and the DXR ${ }^{\mathrm{TM}}$ group $(n=293)$ (Figure 1$)$. All patients provided written informed consent, and the study design was approved by the Research Review Boards/Ethics Committees of each participating institution. This study was conducted according to the principles of the Declaration of Helsinki.

\subsection{Percutaneous Coronary Intervention and Follow-Up}

PCI was performed to treat lesions requiring DES insertion according to the standards of treatment. Approved PCI methods, including directional coronary atherectomy or rotational coronary atherectomy, were used according to the practitioner's judgment. Furthermore, intravascular ultrasound or other monitoring equipment was used, and glycoprotein IIb/IIIa inhibitor or anticoagulant therapy was administered during the procedure according to the treatment standard of the medical institution. Patients were administered aspirin $(300 \mathrm{mg})$ and clopidogrel $(300 \mathrm{mg}) 24 \mathrm{~h}$ prior to the procedure. Unfractionated heparin was administered based on the standard dosage and standard treatment guidelines to achieve an activated clotting time $>250 \mathrm{~s}$, and glycoprotein $\mathrm{IIb} / \mathrm{IIIa}$ was administered according to the practitioner's judgment. The patients were followed up during 1 year after the procedure via outpatient visits or phone calls.

\subsection{Clinical Outcome}

The primary endpoint was 1-year target lesion failure (TLF) defined as a composite of cardiac death, myocardial infarction (MI), and target lesion revascularization (TLR). The secondary endpoints were cardiac death, MI, TLR, stent thrombosis, and stroke.

\subsection{Statistical Analyses}

SPSS for Microsoft Windows (version 20.0, SPSS-PC, Inc. Chicago, IL, USA) was used to conduct the statistical analyses. Continuous variables were compared using the unpaired $t$-test or Mann-Whitney U test, while categorical variables were compared using the chi-squared test and Fisher's exact test. Continuous variables are presented as mean \pm standard deviation and as median values, while categorical variables are presented as total numbers and percentages. The cumulative incidence rate over time was compared and analyzed using the Kaplan-Meier graphs. Univariate Cox proportional hazards regression analyses using baseline clinical, lesion, and procedural variables were performed to identify the predictors of TLF and MI. Variables achieving $p$-values $<0.20$ in the univariate analysis were evaluated in the multivariate analysis to determine the 
independent predictors of clinical events. All tests were two-sided, and $p<0.05$ was considered statistically significant.

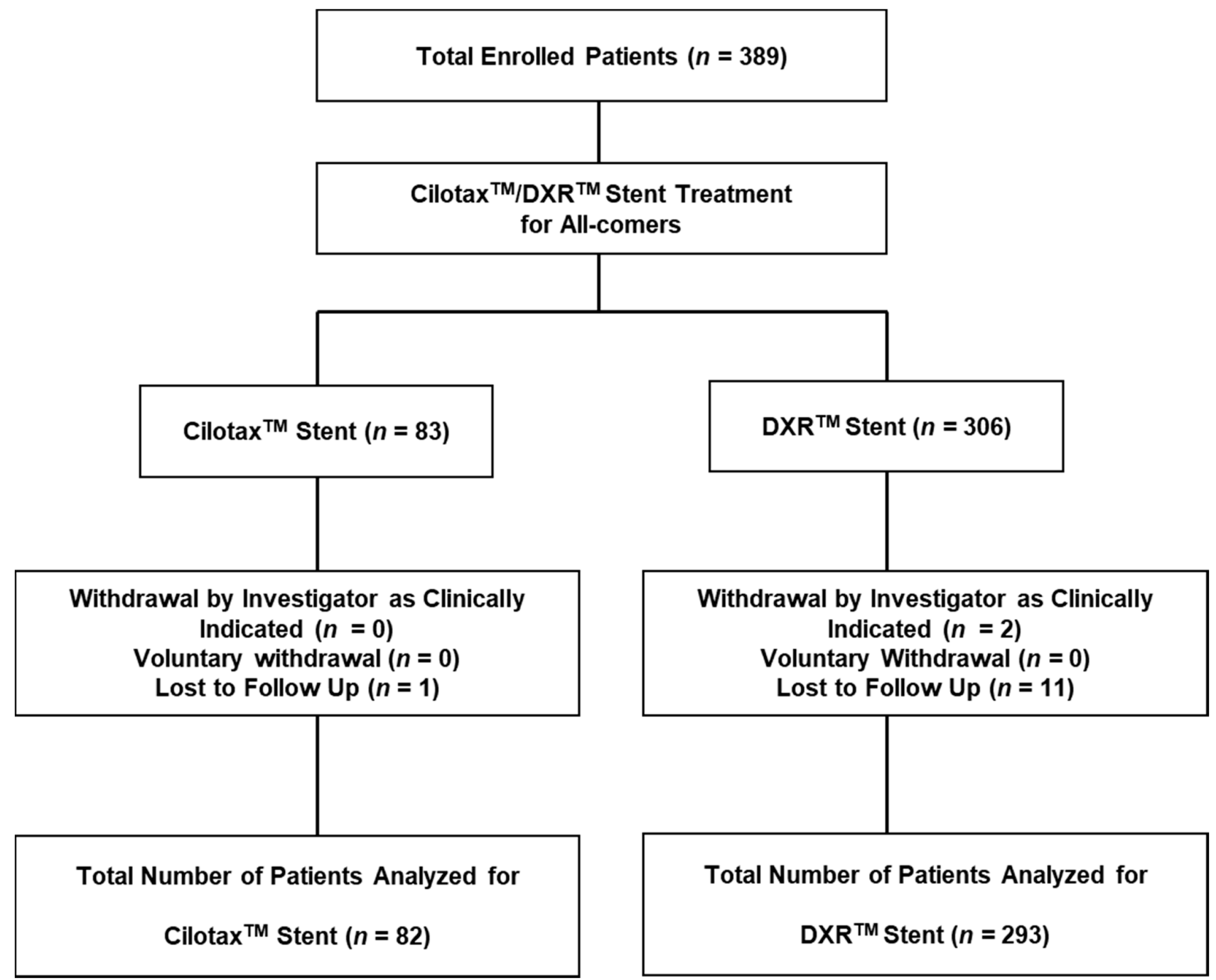

Figure 1. Study flow chart.

3. Results

\subsection{Clinical Characteristics}

No significant differences in clinical characteristics were observed between the Cilotax ${ }^{\mathrm{TM}}$ and DXR ${ }^{\mathrm{TM}}$ groups, with the exception of age, which was higher in the Cilotax ${ }^{\mathrm{TM}}$ group $(69.8 \pm 10.0$ years vs. $65.7 \pm 10.3$ years, $p=0.002)$. The Cilotax ${ }^{\mathrm{TM}}$ group had a higher rate of acute coronary syndrome than the DXR ${ }^{\mathrm{TM}}$ group $(82.9 \%$ vs. $62.5 \%, p<0.001)$ (Table 1$)$.

\subsection{Lesion Characteristics and In-Hospital Outcome}

The average diameter and length of the stent used were $2.9 \pm 0.7 \mathrm{~mm}$ and $22.5 \pm 11.5 \mathrm{~mm}$, respectively. There were no significant differences in the characteristics of lesions in the target vessel, stent diameter, total stent length, or calcified lesion between the two groups, with the exception of the number of treated lesions, which was greater in the Cilotax ${ }^{\mathrm{TM}}$ group $(2.1 \pm 0.8$ vs. $1.6 \pm 0.7, p<0.001)$ (Table 2$)$.

Among the 375 patients, two (0.5\%) died and one $(0.3 \%)$ experienced repeat revascularization during hospitalization. No patient experienced stroke, heart failure, or MI during the hospitalization period. 
Table 1. Patients' baseline characteristics.

\begin{tabular}{|c|c|c|c|c|}
\hline & Total $(n=375)$ & Cilotax $^{\mathrm{TM}}(n=82)$ & $\operatorname{DXR}^{\mathrm{TM}}(n=293)$ & $p$-Value \\
\hline \multicolumn{5}{|l|}{ Demographic data } \\
\hline Sex, male $(\%)$ & $245(65.3)$ & $53(64.5)$ & $192(65.5)$ & 0.985 \\
\hline Age, year & $66.6 \pm 10.4$ & $69.8 \pm 10.0$ & $65.7 \pm 10.3$ & 0.002 \\
\hline Body mass index, $\mathrm{kg} / \mathrm{m}^{2}$ & $25.9 \pm 16.8$ & $24.7 \pm 3.4$ & $26.3 \pm 18.9$ & 0.165 \\
\hline Current smokers, $n(\%)$ & $93(24.8)$ & $19(23.2)$ & $74(25.3)$ & 0.113 \\
\hline Hypertension, $n(\%)$ & $227(60.5)$ & $49(59.8)$ & $178(60.8)$ & 0.972 \\
\hline Diabetes, $n(\%)$ & 127 (33.9) & $28(34.1)$ & $99(33.8)$ & 1.000 \\
\hline Dyslipidemia, $n(\%)$ & $154(41.1)$ & $33(40.2)$ & $121(41.3)$ & 0.965 \\
\hline \multicolumn{5}{|l|}{ History of CAD } \\
\hline Myocardial infarction, $n(\%)$ & $15(4.0)$ & $2(2.4)$ & $13(4.4)$ & 0.619 \\
\hline PCI, $n(\%)$ & $54(14.4)$ & $17(20.7)$ & $37(12.6)$ & 0.095 \\
\hline $\mathrm{CABG}, n(\%)$ & $6(1.6)$ & $2(2.4)$ & $4(1.4)$ & 0.852 \\
\hline Family history of CAD, $n(\%)$ & $10(2.6)$ & $4(4.9)$ & $6(2.0)$ & 0.308 \\
\hline Congestive heart failure, $n(\%)$ & $13(3.5)$ & $4(4.9)$ & $9(3.1)$ & 0.653 \\
\hline Peripheral vascular disease, $n(\%)$ & $7(1.9)$ & $0(0)$ & $7(2.4)$ & 0.341 \\
\hline Stroke, $n(\%)$ & $34(9.1)$ & $11(13.4)$ & $23(7.8)$ & 0.182 \\
\hline Chronic kidney disease, $n(\%)$ & $11(2.9)$ & $2(2.4)$ & $9(3.1)$ & 1.000 \\
\hline Chronic lung disease, $n(\%)$ & $7(1.9)$ & $2(2.4)$ & $5(1.7)$ & 1.000 \\
\hline Clinical presentation & & & & 0.001 \\
\hline Stable angina, $n(\%)$ & $124(33.1)$ & $14(17.1)$ & $110(37.5)$ & \\
\hline Unstable angina, $n(\%)$ & $160(42.7)$ & $39(47.6)$ & $121(41.3)$ & \\
\hline Myocardial infarction, $n(\%)$ & $91(24.3)$ & $29(35.4)$ & $62(21.2)$ & \\
\hline \multicolumn{5}{|l|}{ Discharge Medication } \\
\hline DAPT, $n(\%)$ & $359(95.7)$ & $78(95.1)$ & $281(95.9)$ & 0.759 \\
\hline $\mathrm{ACEi}$ or $\mathrm{ARB}, n(\%)$ & $214(57.1)$ & $49(59.8)$ & $165(56.3)$ & 0.615 \\
\hline Beta blocker, $n(\%)$ & $216(57.6)$ & $51(62.2)$ & $165(56.3)$ & 0.377 \\
\hline Statin, $n(\%)$ & $316(84.3)$ & $68(82.9)$ & $248(84.6)$ & 0.732 \\
\hline DAPT $\geq 12$ months, $n(\%)$ & $330(88.0)$ & $72(87.8)$ & $258(88.1)$ & 1.000 \\
\hline
\end{tabular}

ACEi: Angiotensin-converting-enzyme inhibitor; ARB: Angiotensin II receptor blocker; CAD: coronary artery disease; DAPT: dual antiplatelet therapy; PCI: percutaneous coronary intervention; CABG: coronary artery bypass graft surgery.

Table 2. Angiographic and procedural characteristics.

\begin{tabular}{|c|c|c|c|c|}
\hline & Total $(n=375)$ & Cilotax $^{\mathrm{TM}}(n=82)$ & $\operatorname{DXR}^{\mathrm{TM}}(n=293)$ & $p$-Value \\
\hline Number of treated lesions & $1.6 \pm 5.1$ & $2.1 \pm 0.8$ & $1.6 \pm 0.7$ & $<0.001$ \\
\hline Normal LVEF ( $\geq 50 \%)$ & $355(94.7 \%)$ & $76(92.7 \%)$ & $279(95.2 \%)$ & 0.404 \\
\hline Type of vessel treated & & & & 0.097 \\
\hline Left main, $n(\%)$ & $9(2.4)$ & $5(6.1)$ & $4(1.4)$ & \\
\hline Left arterial descending, $n(\%)$ & $176(46.9)$ & $34(41.5)$ & $142(48.5)$ & \\
\hline Left circumflex, $n(\%)$ & $76(20.3)$ & $16(19.5)$ & $60(20.5)$ & \\
\hline Right coronary artery, $n(\%)$ & $111(29.6)$ & $27(32.9)$ & $84(28.7)$ & \\
\hline Ramus, $n(\%)$ & $3(0.8)$ & $0(0)$ & $3(1.0)$ & \\
\hline Lesion type & & & & 0.298 \\
\hline $\mathrm{A}, n(\%)$ & $45(12.0)$ & $5(6.1)$ & $40(13.7)$ & \\
\hline $\mathrm{B} 1, n(\%)$ & $108(28.8)$ & $22(26.8)$ & $86(28.9)$ & \\
\hline $\mathrm{B} 2, n(\%)$ & $136(36.3)$ & $34(41.5)$ & $102(34.8)$ & \\
\hline C, $n(\%)$ & $86(22.9)$ & $21(25.6)$ & $65(22.2)$ & \\
\hline Calcified lesion, $n(\%)$ & $40(10.6)$ & $6(7.3)$ & $34(11.6)$ & 0.317 \\
\hline Bifurcation lesion, $n(\%)$ & $27(7.2)$ & $4(4.9)$ & $23(7.8)$ & 0.921 \\
\hline Stent diameter, $\mathrm{mm}$ & $2.9 \pm 0.7$ & $2.9 \pm 0.5$ & $2.9 \pm 0.7$ & 0.354 \\
\hline Total stent length, mm & $22.5 \pm 11.4$ & $22.7 \pm 13.8$ & $22.4 \pm 10.6$ & 0.916 \\
\hline IVUS-guided PCI, $n(\%)$ & $69(18.4)$ & $13(15.9)$ & $56(19.2)$ & 0.591 \\
\hline IABP, $n(\%)$ & $21(5.6)$ & $3(3.7)$ & $18(6.1)$ & 0.587 \\
\hline
\end{tabular}

IVUS: intravascular ultrasound; LVEF: left ventricular ejection fraction; PCI: percutaneous coronary intervention; IABP: intra-aortic balloon pump. 


\subsection{Clinical Outcomes at the 1-Year Follow-Up}

TLF occurred in 14 (3.7\%) patients within 1 year after PCI. The cumulative incidence of TLF, death caused by cardiac diseases, MI, and stent thrombosis were significantly higher in the Cilotax ${ }^{\mathrm{TM}}$ group than in the DXR ${ }^{\mathrm{TM}}$ group (TLF, $8.5 \%$ vs. $2.4 \%$, log-rank $p=0.010$; death caused by cardiac diseases, $4.9 \%$ vs. $0.3 \%, \log$-rank $p=0.002 ;$ MI, $6.1 \%$ vs. $1.0 \%, \log$-rank $p=0.005$ and stent thrombosis, $3.7 \%$ vs. $0.3 \%, \log -\operatorname{rank} p=0.009$ ) (Figure 2) (Table 3). The rate of TLR was higher in the Cilotax ${ }^{\mathrm{TM}}$ group, although the difference between the two groups was not significant $(4.9 \%$ vs. $1.7 \%, \log$-rank $p=0.088)$. Approximately $50 \%$ of patients requiring TLR had in-stent restenosis, and there was a similar in-stent restenosis rate between the two groups $(1.2 \%$ vs. $1.0 \%)$. There were no significant differences regarding strokes between the two groups.

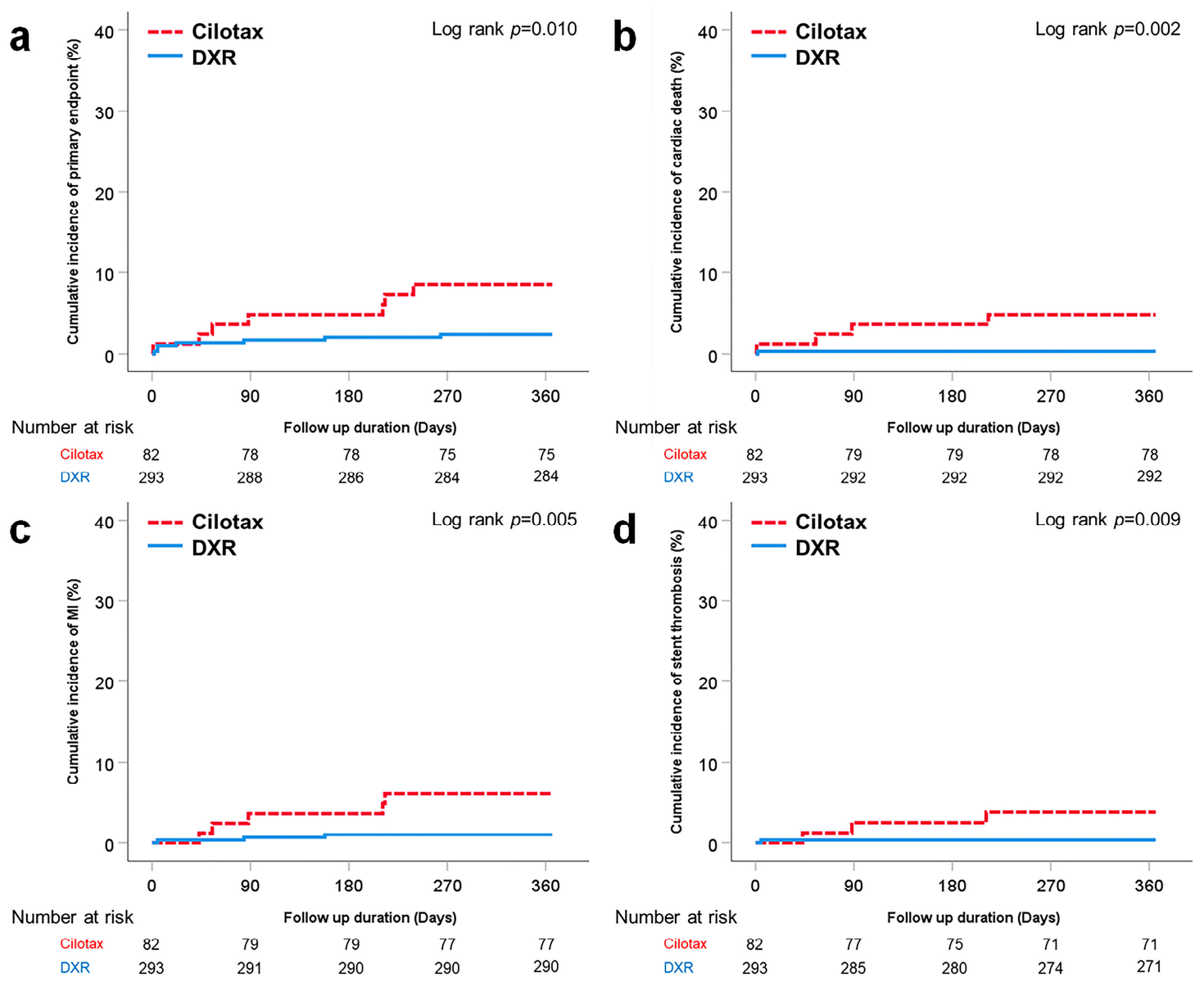

Figure 2. Kaplan-Meier graphs of the cumulative incidence of target lesion failure (a) and its individual componentscardiac death (b), myocardial infarction (c), and stent thrombosis (d).

The Cox regression multivariate analysis revealed that patients in the DXR ${ }^{\mathrm{TM}}$ group had a significantly reduced risk of TLF (adjusted hazard ratio (HR) $0.30,95 \%$ confidence interval (CI) $0.10-0.92, p=0.036$ ) and MI (adjusted HR 0.16, 95\% CI 0.03-0.82, $p=0.027$ ) compared to patients in the Cilotax ${ }^{\mathrm{TM}}$ group (Table 4). 
Table 3. 1-year clinical outcomes on stent type.

\begin{tabular}{ccccc}
\hline & Total $(n=375)$ & Cilotax $(n=82)$ & DXR $(n=293)$ & Log-Rank $p$ \\
\hline $\begin{array}{c}\text { Primary endpoint } \\
\text { Target lesion failure, } n(\%)\end{array}$ & & & & \\
(TLR + MI + Cardiac Death) & $14(3.7)$ & $7(8.5)$ & & 0.023 \\
Secondary endpoints & & & & \\
Cardiac death, $n(\%)$ & $5(1.3)$ & $4(4.9)$ & $3(1.0)$ & 0.002 \\
MI, $n(\%)$ & $8(2.1)$ & $5(6.1)$ & $5(1.7)$ & 0.005 \\
TLR, $n(\%)$ & $9(2.4)$ & $3(4.9)$ & $1(0.3)$ & 0.088 \\
Stent thrombosis, $n(\%)$ & $4(1.1)$ & $3(3.7)$ & $3(1.0)$ & 0.009 \\
Stroke, $n(\%)$ & $6(1.6)$ & $3(3.7)$ & 0.086 \\
\hline
\end{tabular}

TLR: target lesion revascularization; MI: myocardial infarction.

Table 4. Variables associated with target lesion failure.

\begin{tabular}{|c|c|c|c|c|c|c|}
\hline & \multicolumn{3}{|c|}{ Univariate } & \multicolumn{3}{|c|}{ Multivariate } \\
\hline & HR & $95 \%$ CI & $p$-Value & HR & $95 \% \mathrm{CI}$ & $p$-Value \\
\hline Age & 1.04 & $0.98-1.10$ & 0.167 & 1.05 & $0.99-1.11$ & 0.090 \\
\hline Sex & 1.97 & $0.55-7.06$ & 0.298 & & & \\
\hline Hypertension & 0.17 & $0.05-0.62$ & 0.007 & 0.17 & $0.05-0.64$ & 0.009 \\
\hline Diabetes mellitus & 0.44 & $0.10-1.99$ & 0.288 & & & \\
\hline Dyslipidemia & 0.79 & $0.27-2.36$ & 0.675 & & & \\
\hline Chronic kidney disease & 1.03 & $0.23-4.61$ & 0.967 & & & \\
\hline Current smoker & 0.50 & $0.11-2.25$ & 0.369 & & & \\
\hline Previous PCI & 1.63 & $0.46-5.85$ & 0.453 & & & \\
\hline Previous CABG & 4.76 & $0.62-36.67$ & 0.133 & 2.70 & $0.32-22.57$ & 0.359 \\
\hline Previous MI & 4.31 & $0.96-19.25$ & 0.056 & 3.57 & $0.75-17.01$ & 0.110 \\
\hline $\begin{array}{l}\text { Acute coronary } \\
\text { syndrome }\end{array}$ & 2.97 & $0.66-13.26$ & 0.154 & 1.77 & $0.37-8.48$ & 0.473 \\
\hline Bifurcation lesion & 2.57 & $0.80-8.18$ & 0.111 & 2.92 & $0.86-9.91$ & 0.086 \\
\hline DXR stent & 0.27 & $0.10-0.78$ & 0.016 & 0.30 & $0.09-0.92$ & 0.036 \\
\hline IVUS-guidance PCI & 0.42 & $0.04-4.46$ & 0.289 & & & \\
\hline Total number of stents & 1.04 & $0.28-3.88$ & 0.953 & & & \\
\hline Total lesion length & 1.00 & $0.96-1.05$ & 0.945 & & & \\
\hline
\end{tabular}

PCI: percutaneous coronary intervention; CABG: coronary artery bypass graft surgery; MI: myocardial infarction; IVUS: intravascular ultrasound.

\section{Discussion}

The incidence of TLF during the 1-year clinical follow-up of 375 patients who underwent PCI using dual-DES for the treatment of coronary artery diseases at 13 hospitals in South Korea was 3.7\%, which is comparable to the reported incidence of TLF after the use of conventional DESs. Additionally, the rate of TLF in the DXR ${ }^{\mathrm{TM}}$ group was significantly lower than that in the Cilotax ${ }^{\mathrm{TM}}$ group. Patients in the $\mathrm{DXR}^{\mathrm{TM}}$ group were also less likely to experience $\mathrm{MI}$ and death caused by cardiac diseases than patients in the Cilotax ${ }^{\mathrm{TM}}$ group.

Despite the risk of restenosis and the complexity of PCI, most current DES systems elute a single drug; however, recently, stents with two drugs that target various stages of restenosis have been developed. In the ISAR-TEST-2 trial [15] comparing the safety and efficacy of dual-DESs (sirolimus and probucol) and single DESs (sirolimus or zotarolimus), no differences in the occurrences of stent thrombosis or MI were found between the three different stents until 2 years after PCI. However, a significantly lower target lesion reintervention rate was reported in the dual-DES group than in the sirolimus stent group between the first and the second year. Therefore, dual-DESs, which had two drugs to target various stages of the restenosis reaction, were thought to be more effective to prevent restenosis beyond 1 year after PCI.

The dual-DESs included in this study were composed of cilostazol and paclitaxel and have been developed in South Korea to improve the efficacy and safety of conventional paclitaxel-eluting stents. Cilostazol is an antiplatelet drug with similar effects as 
ticlopidine and clopidogrel, selectively inhibiting phosphodiesterase III [7-10]. The combined use of cilostazol with aspirin and clopidogrel prevents stent thrombosis after a stent procedure [16]. In addition, cilostazol, a phosphodiesterase III inhibitor, has antiproliferative effects in terms of decreasing intimal hyperplasia and restenosis in patients after BMS and DES implantation [11-14,17]. The Cilotax ${ }^{\mathrm{TM}}$ dual-DES is a thin stent $(77 \mu \mathrm{m})$ manufactured using L605 cobalt chrome, while the drug delivery polymer consists of a combination of hydrophile, biocompatible cellulose acetate butyrate, and a bioabsorbable resomer. Paclitaxel $\left(1 \mu \mathrm{g} / \mathrm{mm}^{2}\right)$ and cilostazol $\left(6 \mu \mathrm{g} / \mathrm{mm}^{2}\right)$ are mostly eluted within 1 and 6 months, respectively. Cilostazol is eluted slowly, which helps to prevent the formation of a partial thrombus around the stent, thereby preventing early stent thrombosis. The safety and efficacy of the Cilotax ${ }^{\mathrm{TM}}$ dual-DES has been proven using a coronary artery model in pigs and in an early clinical study, which reported significantly less late lumen loss compared to a paclitaxel-eluting stent (Taxus Liberte ${ }^{\mathrm{TM}}$ ) [18]. Compared to the Cilotax ${ }^{\mathrm{TM}}$ dual-DES, the DXR ${ }^{\mathrm{TM}}$ dual-DES has an improved polymer coating with a thickness of $6 \mu \mathrm{m}$. The thickness of the drug coating of the DXR ${ }^{\mathrm{TM}}$ dual-DES is $<10 \mu \mathrm{m}$, which is more than $30 \%$ less than that of the Cilotax ${ }^{\mathrm{TM}}$ dual-DES. Furthermore, the DXR ${ }^{\mathrm{TM}}$ dual-DES has an increased polymer degradation rate compared to the Cilotax ${ }^{\mathrm{TM}}$ dual-DES. Both the proximal shaft and distal shaft of the delivery system of the DXR ${ }^{\text {TM }}$ dual-DES are thinner than those of the Cilotax ${ }^{\mathrm{TM}}$ dual-DES, rendering the $\mathrm{DXR}^{\mathrm{TM}}$ dual-DEC easier to deliver.

The incidence of 1-year TLF was $8.5 \%$ in the Cilotax ${ }^{\mathrm{TM}}$ group and $2.7 \%$ in the DXR ${ }^{\mathrm{TM}}$ group. The DXR group had more favorable clinical outcomes in terms of the primary endpoint, cardiac death, and MI. Fewer patients in the DXR ${ }^{\mathrm{TM}}$ group underwent TLR. In a previous report, the Cilotax ${ }^{\mathrm{TM}}$ dual-DES was reported to have a higher incidence of adverse outcomes than the second-generation DES [19]. A plausible explanation is that the Cilotax ${ }^{\mathrm{TM}}$ dual-DES have polymer inhomogeneity and an unstable drug elution period. In context, the DXR ${ }^{\mathrm{TM}}$ dual-DES was developed to overcome the problems of the Cilotax ${ }^{\mathrm{TM}}$ dual-DES, and our study results revealed more favorable clinical outcomes of the DXR ${ }^{\mathrm{TM}}$ dual-DES. Additionally, although the incidence of TLF in the Cilotax ${ }^{\mathrm{TM}}$ group was $8.5 \%$, the incidence of TLF in the DXR ${ }^{\mathrm{TM}}$ group was $2.4 \%$, which shows comparable or better results of third-generation DES [20-24].

Stent thrombosis occurred in four $(1.1 \%)$ patients in this study, three of whom were in the Cilotax ${ }^{\mathrm{TM}}$ group. The rate of stent thrombosis in the Cilotax ${ }^{\mathrm{TM}}$ group was higher in this study than in previous reports $[20,21,23]$. Although the Cilotax ${ }^{\mathrm{TM}}$ group more conducted PCI in the patients with a high risk of stent thrombosis, the increased rate of stent thrombosis in the Cilotax ${ }^{\mathrm{TM}}$ group observed in this study may be due to structural limitations of the Cilotax ${ }^{\mathrm{TM}}$ dual-DES. In contrast, in the DXR ${ }^{\mathrm{TM}}$ group, subacute stent thrombosis occurred in one $(0.3 \%)$ patient, which is consistent with the results of the BIO-RESORT trial [25] and other recent studies [20,21,23,24].

This study has several limitations. First, this study included a relatively small number of patients to assess restenosis in two dual-DESs. As the DXR ${ }^{\mathrm{TM}}$ dual-DES was developed as the next generation of dual-DESs after the Cilotax ${ }^{\mathrm{TM}}$ dual-DES, the number of patients in the Cilotax ${ }^{\mathrm{TM}}$ group was less than the number of patients in the DXR ${ }^{\mathrm{TM}}$ group. Thus, the superior results of the DXR ${ }^{\mathrm{TM}}$ dual-DES should be interpreted with caution. However, this is the first study to compare the dual-DESs developed in South Korea. Therefore, the results of this study will be helpful in the development of dual-DES in the future. Second, since our study aimed at the one-year efficacy and safety of dual DES, evidence of long-term clinical outcomes of dual DES for restenosis or stent thrombosis is lacking. Thus, further studies will need to include longer-term follow up on a wider sample of patients. Third, this study was conducted based on the combination of aspirin and clopidogrel. Thus, it should be considered that potent P2Y12 inhibitors may bring to have better clinical outcomes, especially in acute coronary syndrome. However, although the rate of patients who presented acute coronary syndrome was higher than those of stable angina in this study, clinical outcomes were comparable that those using conventional DESs. In context, further 
investigation is needed to provide the clinical impact of using potent P2Y12 inhibitors in dual DES.

\section{Conclusions}

The use of dual-DESs containing paclitaxel and cilostazol results in comparable efficacy and safety clinical outcomes compared to the use of current DESs. The efficacy and safety of the DXR ${ }^{\mathrm{TM}}$ dual-DES are even more pronounced than those of the Cilotax ${ }^{\mathrm{TM}}$ dual-DES.

Author Contributions: Conceptualization, J.-J.C. and G.C.K.; methodology, J.-J.C. and G.C.K.; software, J.-J.C.; validation, J.-J.C., G.C.K. and T.H.A.; formal analysis, J.-J.C.; investigation, J.-J.C. and T.H.A.; resources, S.H.H., J.H.B., J.W.C., D.-K.J., S.I.W., S.U.L., J.S.P., Y.-H.C., C.U.C., D.-S.L., and T.H.A.; data curation, J.-J.C. and G.C.K.; writing—original draft preparation, J.-J.C.; writing-review and editing, J.-J.C., G.C.K. and T.H.A.; visualization, J.-J.C.; supervision, S.H.H., J.H.B., J.W.C., D.-K.J., S.I.W., S.U.L., J.S.P., Y.-H.C., C.U.C., D.-S.L. and T.H.A.; project administration, T.H.A.; funding acquisition, J.-J.C. and T.H.A. All authors have read and agreed to the published version of the manuscript.

Funding: This research was funded by Korea University Anam Hospital, Seoul, Repulic of Korea, Grant No. O2000761.

Institutional Review Board Statement: The study was conducted according to the guidelines of the Declaration of Helsinki, and approved by the Institutional Review Board of each participating institution including Gachon University Gil Hospital (GIRBD0028-2012).

Informed Consent Statement: Informed consent was obtained from all subjects involved in the study.

Data Availability Statement: Data available on request due to restrictions eg privacy or ethical. The data presented in this study are available on request from the corresponding author.

Conflicts of Interest: The authors declare no conflict of interest.

\section{References}

1. Stefanini, G.G.; Holmes, D.R. Drug-eluting coronary-artery stents. N. Engl. J. Med. 2013, 368, 254-265. [CrossRef] [PubMed]

2. Shin, E.-S. Current status of coronary stent. Korean J. Med. 2015, 89, 282-290. [CrossRef]

3. Camenzind, E.; Steg, P.G.; Wijns, W. Stent thrombosis late after implantation of first-generation drug-eluting stents: A cause for concern. Circulation 2007, 115, 1440-1455. [CrossRef] [PubMed]

4. Joner, M.; Finn, A.V.; Farb, A.; Mont, E.K.; Kolodgie, F.D.; Ladich, E.; Kutys, R.; Skorija, K.; Gold, H.K.; Virmani, R. Pathology of drug-eluting stents in humans: Delayed healing and late thrombotic risk. J. Am. Coll. Cardiol. 2006, 48, 193-202. [CrossRef] [PubMed]

5. $\quad$ Daemen, J.; Wenaweser, P.; Tsuchida, K.; Abrecht, L.; Vaina, S.; Morger, C.; Kukreja, N.; Jüni, P.; Sianos, G.; Hellige, G.; et al. Early and late coronary stent thrombosis of sirolimus-eluting and paclitaxel-eluting stents in routine clinical practice: Data from a large two-institutional cohort study. Lancet 2007, 369, 667-678. [CrossRef]

6. Montalescot, G.; Hulot, J.S.; Collet, J.P. Stent thrombosis: Who's guilty? Eur. Heart J. 2009, 30, 2685-2688. [CrossRef]

7. Kunishima, T.; Musha, H.; Eto, F.; Iwasaki, T.; Nagashima, J.; Masui, Y.; So, T.; Nakamura, T.; Oohama, N.; Murayama, M. A randomized trial of aspirin versus cilostazol therapy after successful coronary stent implantation. Clin. Ther. 1997, 19, 1058-1066. [CrossRef]

8. Angiolillo, D.J.; Capranzano, P.; Goto, S.; Aslam, M.; Desai, B.; Charlton, R.K.; Suzuki, Y.; Box, L.C.; Shoemaker, S.B.; Zenni, M.M.; et al. A randomized study assessing the impact of cilostazol on platelet function profiles in patients with diabetes mellitus and coronary artery disease on dual antiplatelet therapy: Results of the OPTIMUS-2 study. Eur. Heart J. 2008, 29, 2202-2211. [CrossRef]

9. Park, S.W.; Lee, C.W.; Kim, H.S.; Lee, H.J.; Park, H.K.; Hong, M.K.; Kim, J.; Park, S.J. Comparison of cilostazol versus ticlopidine therapy after stent implantation. Am. J. Cardiol. 1999, 84, 511-514. [CrossRef]

10. Lee, S.W.; Park, S.W.; Hong, M.K.; Lee, C.W.; Kim, Y.H.; Park, J.H.; Kang, S.J.; Han, K.H.; Kim, J.J.; Park, S.J. Comparison of cilostazol and clopidogrel after successful coronary stenting. Am. J. Cardiol. 2005, 95, 859-862. [CrossRef]

11. Douglas, J.S., Jr.; Holmes, D.R., Jr.; Kereiakes, D.J.; Grines, C.L.; Block, E.; Ghazzal, Z.; Morris, D.C.; Liberman, H.; Parker, K.; Jurkovitz, C.; et al. Coronary stent restenosis in patients treated with cilostazol. Circulation 2005, 112, 2826-2832. [CrossRef] [PubMed]

12. Inoue, T.; Uchida, T.; Sakuma, M.; Imoto, Y.; Ozeki, Y.; Ozaki, Y.; Hikichi, Y.; Node, K. Cilostazol inhibits leukocyte integrin Mac-1, leading to a potential reduction in restenosis after coronary stent implantation. J. Am. Coll. Cardiol. 2004, 44, 1408-1414. [CrossRef] [PubMed] 
13. Lee, S.W.; Park, S.W.; Kim, Y.H.; Yun, S.C.; Park, D.W.; Lee, C.W.; Hong, M.K.; Kim, H.S.; Ko, J.K.; Park, J.H.; et al. Drug-eluting stenting followed by cilostazol treatment reduces late restenosis in patients with diabetes mellitus the DECLARE-DIABETES Trial (A Randomized Comparison of Triple Antiplatelet Therapy with Dual Antiplatelet Therapy After Drug-Eluting Stent Implantation in Diabetic Patients). J. Am. Coll. Cardiol. 2008, 51, 1181-1187. [CrossRef] [PubMed]

14. Tamhane, U.; Meier, P.; Chetcuti, S.; Chen, K.Y.; Rha, S.-W.; Grossman, M.P.; Gurm, H.S. Efficacy of cilostazol in reducing restenosis in patients undergoing contemporary stent based PCI: A meta-analysis of randomised controlled trials. EuroIntervention 2009, 5, 384-393. [CrossRef] [PubMed]

15. Byrne, R.A.; Kastrati, A.; Tiroch, K.; Schulz, S.; Pache, J.; Pinieck, S.; Massberg, S.; Seyfarth, M.; Laugwitz, K.L.; Birkmeier, K.A.; et al. 2-year clinical and angiographic outcomes from a randomized trial of polymer-free dual drug-eluting stents versus polymer-based cypher and endeavor, drug-eluting stents. J. Am. Coll. Cardiol. 2010, 55, 2536-2543. [CrossRef] [PubMed]

16. Lee, S.; Park, S.W.; Hong, M.K.; Kim, Y.H.; Lee, B.K.; Song, J.M.; Han, K.H.; Lee, C.W.; Kang, D.H.; Song, J.K.; et al. Triple versus dual antiplatelet therapy after coronary stenting. J. Am. Coll. Cardiol. 2005, 46, 1833-1837. [CrossRef] [PubMed]

17. Ahn, Y.; Jeong, M.H.; Jeong, J.W.; Kim, K.H.; Ahn, T.H.; Kang, W.C.; Park, C.G.; Kim, J.H.; Chae, I.H.; Nam, C.W.; et al. Randomized comparison of cilostazol vs clopidogrel after drug-eluting stenting in diabetic patients-Clilostazol for diabetic patients in drug-eluting stent (CIDES) trial. Circ. J. 2008, 72, 35-39. [CrossRef]

18. Lee, C.W.; Park, D.; Seung, K.B.; Kim, P.J.; Park, H.J.; Kim, W.J.; Lee, J.Y.; Kang, S.J.; Lee, S.H.; Kim, Y.H.; et al. Comparison of dual drug-eluting cilotax stent and paclitaxel-eluting taxus liberte stent in native coronary artery lesions. Am. J. Cardiol. 2011, 107, 990-994. [CrossRef]

19. Jihun, A.; Rha, S. CRT-100.23 Comparison of dual drug-eluting stent (cilotax) and everolimus-eluting stents in patients with st-elevation myocardial infarction (STEMI): 3-years clinical outcomes. J. Am. Coll. Cardiol. Cardiovasc. Interv. 2017, 10, S9. [CrossRef]

20. Von Birgelen, C.; Zocca, P.; Buiten, R.A.; Jessurun, G.A.J.; Schotborgh, C.E.; Roguin, A.; Danse, P.W.; Benit, E.; Aminian, A.; Van Houwelingen, K.G.; et al. Thin composite wire strut, durable polymer-coated (Resolute Onyx) versus ultrathin cobaltchromium strut, bioresorbable polymer-coated (Orsiro) drug-eluting stents in allcomers with coronary artery disease (BIONYX): An international, single-blind, randomised non-inferiority trial. Lancet 2018, 392, 1235-1245. [CrossRef]

21. Pilgrim, T.; Heg, D.; Roffi, M.; Tüller, D.; Muller, O.; Vuilliomenet, A.; Cook, S.; Weilenmann, D.; Kaiser, C.; Jamshidi, P.; et al. Ultrathin strut biodegradable polymer sirolimus-eluting stent versus durable polymer everolimus-eluting stent for percutaneous coronary revascularisation (BIOSCIENCE): A randomised, single-blind, non-inferiority trial. Lancet 2014, 384, $2111-2122$. [CrossRef]

22. Ananthakrishna, R.; Kristanto, W.; Liu, L.; Chan, S.-P.; Loh, P.H.; Tay, E.L.; Chan, K.H.; Chan, M.Y.; Lee, C.-H.; Low, A.F.; et al. Incidence and predictors of target lesion failure in a multiethnic Asian population receiving the SYNERGY coronary stent: A prospective all-comers registry. Catheter. Cardiovasc. Interv. 2018, 92, 1097-1103. [CrossRef] [PubMed]

23. Kaul, U.; Bangalore, S.; Seth, A.; Arambam, P.; Abhaichand, R.K.; Patel, T.; Banker, D.; Abhyankar, A.; Mullasari, A.S.; Shah, S.A.; et al. Paclitaxel-eluting versus everolimus-eluting coronary stents in diabetes. N. Engl. J. Med. 2015, 373, 1709-1719. [CrossRef] [PubMed]

24. Buchanan, G.L.; Basavarajaiah, S.; Chieffo, A. Stent thrombosis: Incidence, predictors and new technologies. Thrombosis 2012, 2012, 956962. [CrossRef] [PubMed]

25. Von Birgelen, C.; Kok, M.M.; Van Der Heijden, L.C.; Danse, P.W.; Schotborgh, C.E.; Scholte, M.; Gin, R.M.T.J.; Somi, S.; Van Houwelingen, K.; Stoel, M.; et al. Very thin strut biodegradable polymer everolimus-eluting and sirolimus-eluting stents versus durable polymer zotarolimus-eluting stents in allcomers with coronary artery disease (BIO-RESORT): A three-arm, randomised, non-inferiority trial. Lancet 2016, 388, 2607-2617. [CrossRef] 